\title{
WOJNA ETYCZNIE USPRAWIEDLIWIONA W ŚWIETLE KATOLICKIEJ NAUKI SPOŁECZNEJ
}

\begin{abstract}
Streszczenie. Artykuł prezentuje podstawowe założenia filozoficzno-moralne leżące u podłoża ocen działań militarnych formułowanych w obrębie katolickiej nauki społecznej. Wskazując na ciągłość nauczania Kościoła odnoszącego się do etycznego aspektu konfliktów zbrojnych oraz jego głębokie osadzenie w wielowiekowej tradycji filozofii chrześcijańskiej, autor zwraca uwagę na uwidaczniające się we współczesnym stanowisku Kościoła przesunięcie akcentu z przypisywania wartości wojnie jako takiej na uzasadnianie konieczności obrony pokoju - w określonych warunkach obejmującej również zastosowanie środków militarnych.
\end{abstract}

Słowa kluczowe: etyka wojny, wojna etycznie usprawiedliwiona, uprawnienia suwerennych państw, wojna obronna, interwencja zbrojna

1. Wstęp. 2. Wokół pojęcia wojny etycznie usprawiedliwionej. 3. Rodzaje wojen etycznie usprawiedliwionych. 4. Zakończenie.

\section{WSTĘP}

Problematyka pokoju i wojny nie jest sprawą obojętną Kościołowi, a wręcz przeciwnie w myśli społecznej Kościoła zajmuje ona centralne miejsce w tzw. dziale życia międzynarodowego. W tym miejscu należy jednak podkreślić, iż myśl społeczna Kościoła uznając ścisłą relację pomiędzy pokojem a wojną zdecydowany priorytet przyznaje nauczaniu na temat pokoju. Ta tematyka zajmuje miejsce centralne i fundamentalne, choć nie zawsze tak było. Dawniej dominował w etyce społecznej Kościoła problem godziwości prowadzenia wojny. W ostatnich, szczególnie posoborowych, czasach nastąpiła zmiana orientacji. Stąd gros nauki w tej szerokiej problematyce oscyluje wokół pokoju. Pokój bowiem uważany jest za fundamentalną wartość dla 
życia człowieka jako jednostki i wspólnoty osób. Tymczasem wojna nie jest wartością, a może jedynie w niektórych przypadkach być uznana za obronę wartości.

Można zatem powiedzieć, że nauka społeczna Kościoła głosi kult pokoju. W tym miejscu dodać jednak i podkreślić należy, iż nie jest to głoszenie kultu pokoju „za wszelką cenę”, czyli nie kosztem fundamentalnych wartości moralnych człowieka i społeczeństwa. Nauka społeczna Kościoła będąc etyką pokoju, nie jest mimo to bezkrytycznym pacyfizmem. Oznacza to, że nauka społeczna Kościoła wypracowała także własną teorię wojny - wojny etycznie usprawiedliwionej.

\section{WOKÓŁ POJĘCIA WOJNY ETYCZNIE USPRAWIEDLIWIONEJ}

Jak wspomniano powyżej, katolicka nauka społeczna nie jest bezkrytycznym pacyfizmem. Kościół bowiem widzi realistycznie istniejącą sytuację świata i stwierdza, że wojny jako takiej nie dało się wykorzenić $\mathrm{z}$ zakresu spraw życia państwowego w jego wymiarze międzynarodowym. Co więcej, jak stwierdza S. Olejnik „realistyczna ocena sytuacji każe mu powstrzymywać słowa zupełnego potępienia wszelkiego rodzaju wojny jako takiej. Potępienie bowiem wojny w ogóle mogłoby być równoznaczne z otwarciem drogi do bezkarnego działania cynicznej, wyzbytej wszelkiego poczucia odpowiedzialności, agresji w stosunkach międzynarodowych".

Nauka społeczna Kościoła głosi zatem, że dopóki nie dojdzie do powstania jakiejś władzy międzynarodowej, która mogłaby rozstrzygać spory i posiadałaby siłę niezbędną do wymuszania swych decyzji „póty rządom nie można zaprzeczać prawa do wojny, byle wyczerpały wpierw środki pokojowych rokowań”2. Można

1 S. Olejnik, W odpowiedzi na dar i powołanie Boże. Zarys teologii moralnej, Warszawa 1979, 782.

2 Sobór Watykański II, Konstytucja duszpasterska o Kościele w świecie współczesnym, w: Sobór Watykański II, Konstytucje, deklaracje, dekrety, tekst polski, Poznań 1986, 537-620. 
nawet powiedzieć, iż katolicka nauka społeczna wypracowała swoją doktrynę wojny jako ostatecznego działania państwa wobec innego państwa. Jest to tzw. wojna etycznie usprawiedliwiona. Należy ją zatem w tym momencie nieco przybliżyć.

Nauka społeczna Kościoła podkreśla, że wojna nie jest tylko i wyłącznie zjawiskiem społecznym dotyczącym określonych państw i społeczności międzynarodowej, ale także faktem etycznym. Oznacza to, iż podlega ona etycznemu wartościowaniu, przy czy dodać należy, iż nigdy nie jest ona uznawana i oceniana jako dobro lub wartość, ale jedynie w niektórych przypadkach uznana być może za obronę wartości, a tym samym usprawiedliwiona ${ }^{3}$. Stąd też katolicka nauka społeczna mówi o tak zwanej wojnie etycznie usprawiedliwionej. Co zatem ujmuje Kościół w teorii wojny etycznie usprawiedliwionej?

Najogólniej pod pojęciem tej wojny nauka społeczna Kościoła rozumie taką sytuację: „,kiedy określone państwo podejmuje walkę zbrojną $\mathrm{w}$ obronie fundamentalnych swych praw zagrożonych lub w celu ich restytucji kierując się przy tym dobrą, czyli etycznie godziwą intencję"4. W pojęciu tak rozumianej i definiowanej wojny etycznie usprawiedliwionej kryją się dwa fundamentalne elementy, które należy wyjaśnić.

Pierwszym z nich jest dobra intencja, która określa: „moralną stronę duchowej postawy kierowników państwa wciągniętych w sytuację konfliktu zbrojnego" "S. Strukturę dobrej intencji kształtują trzy czynniki. Pierwszym jest traktowanie wojny jako kroku ostatecznego niejako wymuszonego faktem, iż nie było można zastosować środków pokojowego załagodzenia konfliktu albo środki tego rodzaju zostały wyczerpane bez właściwego rezultatu. Drugim uzasadnione przewidywanie przez prowadzących wojnę pomyślnego jej zakończenia.

3 Por. T. Ślipko, Zarys etyki szczegółowej, Kraków 1982, 336.

4 Tamże, 344.

5 Tamże, 339. 
Trzecim prowadzenie działań zmierzających do ograniczenia towarzyszących wojnie okrucieństw, czyli tzw. humanizacja działań.

Można zatem powiedzieć, iż dobra intencja jako pierwszy element wojny etycznie usprawiedliwionej zawiera $\mathrm{w}$ sobie trzy ważne postulaty: sprowadzenie wojny do ostatecznego środka rozstrzygania sporów, humanitarnego sposobu jej prowadzenia oraz roztropnej oceny realnych szans na pomyślne jej zakończenie ${ }^{6}$.

Drugim fundamentalnym elementem wojny etycznie usprawiedliwionej jest słuszna przyczyna. Najogólniej pod pojęciem tym katolicka nauka społeczna rozumie: „obronę pogwałconej sprawiedliwości, czyli reakcję na jakąś wyrządzoną danemu państwu krzywdę, niesprawiedliwość". Takie ujęcie słusznej przyczyny domaga się wyjaśnienia. Trzeba bowiem postawić pytanie: co oznacza określenie „pogwałcona sprawiedliwość” i w czym się ona wyraża?

Pojęcie to oznacza naruszenie podstawowych, naturalnych i niezbywalnych praw, które są należne każdemu bytowi państwowemu, a z których najważniejsze to: prawo do istnienia, suwerenności i niepodległości, integralności terytorialnej, swobodnego rozwoju życia społeczno-gospodarczo-kulturowego ${ }^{8}$. Naruszenie tych właśnie praw jest słuszną przyczyną podjęcia działań wojennych. Dodać także w tym miejscu należy, iż naruszenie to może mieć podwójny charakter. W pierwszej kolejności chodzi o naruszenie wspomnianych praw poprzez tzw. agresję aktualną, która ma miejsce wtedy, gdy określone państwo podejmuje działania zbrojne wobec drugiego państwa. W drugiej kolejności chodzi jednak także o naruszenie wspomnianych praw poprzez agresję dokonaną, która polega na utrwalonym już stanie niesprawiedliwości spowodowanej

6 Por. tamże, 339-440.

7 Tamże, 44.

8 Por. Cz. Strzeszewski, Własność. Zagadnienia społeczno-moralne, Warszawa 1981, 544-548. 
wcześniejszym aktem pozbawienia jakiegoś państwa należnego mu prawa.

Można zatem powiedzieć, że słuszna przyczyna, jako drugi fundamentalny element wojny etycznie usprawiedliwionej, to naruszenie podstawowych praw należnych każdemu bytowi państwowemu $\mathrm{w}$ formie agresji aktualnej lub dokonanej.

Tak nauka społeczna Kościoła definiuje teorię wojny etycznie usprawiedliwionej. Jest to walka zbrojna w obronie fundamentalnych praw państwa zagrożonych aktualnie lub w celu ich restytucji, kierując się przy tym dobrą, czyli etycznie godziwą intencją.

Określenie i zdefiniowanie pojęcia wojny etycznie usprawiedliwionej, jedynej akceptowanej przez katolicką naukę społeczną, nie kończy całego problemu wojny i jej etycznej oceny. Jest to bowiem określenie ogólne. Dopiero w jego świetle można rozstrzygnąć jakie rodzaje wojny są faktycznie usprawiedliwione, tzn. jakie rodzaje wojen może konkretne państwo prowadzić. Nie ulega bowiem wątpliwości, iż w praktyce mamy do czynienia z różnego rodzaju wojnami.

\section{RODZAJE WOJEN ETYCZNIE USPRAWIEDLIWIONYCH}

Jakie zatem wojny można etycznie usprawiedliwić w świetle katolickiej nauki społecznej? W pierwszej kolejności do tego rodzaju wojny zaliczyć należy wojnę militarnie defensywną (obronną) podjętą dla odparcia aktualnie dokonywanej agresji. Pojęcie wojny militarnie defensywnej wyraża: „działania wojenne podjęte w odpowiedzi na rozpoczętą już ofensywę ze strony przeciwnika” ${ }^{10}$. Problem oceny tej wojny jest stosunkowo prosty. Każde bowiem państwo ma prawo bronić swoich naturalnych i niezbywalnych praw. Jeżeli zostają one zatem naruszone przez inne państwo, a nie ma w życiu

9 Por. T. Ślipko, dz. cyt., 342.

10 Tamże, 335. 
międzynarodowym skutecznej instancji ponadpaństwowej, każde państwo ma prawo bronić się samodzielnie.

Do wojny etycznie usprawiedliwionej katolicka nauka społeczna zalicza także wojnę militarnie ofensywną dla restytucji naruszonych uprzednio praw. Dodać przy tym należy, iż przez ten rodzaj wojny rozumie się „inicjatywę militarną określonego państwa, w której rozpoczyna ono jako pierwsze działania wojenne przeciwko innemu państwu i występuje jako strona atakująca"11. Podstawową racją etycznie usprawiedliwiającą tego rodzaju wojnę jest potrzeba restytucji utraconego dobra, jakim są wspomniane prawa. Jeżeli nie ma zatem czynników międzynarodowych, które by te sprawy regulowały, istnieje możliwość odzyskania utraconego dobra samemu. Biorąc jednak pod uwagę, że w dzisiejszej dobie w warunkach posuwającej się rozbudowy instytucji międzynarodowych form rozjemstwa i arbitrażu, maleje stosowalność tej zasady, także i tego rodzaju wojna będzie należeć do wyjątków ${ }^{12}$.

Wreszcie do wojny etycznie usprawiedliwionej w świetle katolickiej nauki społecznej zaliczyć należy tzw. wojnę interwencyjną. Rozumie się przez nią: „akcję zbrojną określonego państwa na rzecz jednej ze stron już zaangażowanych w prowadzenie wojny" ${ }^{13}$. Chodzi oczywiście o taką sytuację, gdzie państwo, które jest wspierane, toczy wojnę defensywną celem obrony swych zagrożonych praw lub celem restytucji tych praw. Na ocenę pozytywną tego rodzaju wojny wpływa zasada o możliwości pomocy podmiotowi, który zmierza do dobra. Jeśli zatem określone państwo prowadzi wojnę celem obrony albo restytucji swoich praw, to należy to uznać za cel dobry. Wsparcie takiego państwa jest działaniem etycznie usprawiedliwionym.

11 Tamże.

12 Por. tamże, 350.

13 Tamże, 335. 


\section{ZAKOŃCZENIE}

Podsumowując refleksje niniejszego punktu, raz jeszcze podkreślić należy, iż katolicka nauka społeczna nie odbiera państwom możliwości prowadzenia wojny. Chodzi jednak tylko i wyłącznie o wojnę etycznie usprawiedliwioną. $\mathrm{W}$ jej zaś zakres wchodzą trzy rodzaje wojen: wojna defensywna podjęta dla obrony zagrożonych praw; wojna ofensywna celem restytucji naruszonego dobra; wojna interwencyjna dla wsparcia państwa walczącego o swoje zagrożone lub naruszone prawa.

Poza pojęciem wojny etycznie nieusprawiedliwionej usytuować należy: wojnę ofensywną zaborczą, wojnę interwencyjną wspierającą państwo dokonujące agresji, wojnę prewencyjną, a więc wojnę podjętą przez jedno państwo przeciwko drugiemu jedynie ze względu na rosnący jego potencjał ekonomiczny lub polityczny.

\section{BIBLIOGRAFIA}

Olejnik S., W odpowiedzi na dar i powotanie Boże. Zarys teologii moralnej, Wydawnictwo Akademii Teologii Katolickiej, Warszawa 1979.

Sobór Watykański II, Konstytucja duszpasterska o Kościele w świecie wspótczesnym, w: Sobór Watykañski II, Konstytucje, deklaracje, dekrety, tekst polski, Pallotinum, Poznań 1986.

Strzeszewski Cz., Wtasność. Zagadnienia spoteczno-moralne, Ośrodek Dokumentacji i Studiów Społecznych, Warszawa 1981.

Ślipko T., Zarys etyki szczegótowej, WAM, Kraków 1982.

\section{THE MORAL JUSTIFICATION OF WAR IN LIGHT OF CATHOLIC SOCIAL TEACHING}

\footnotetext{
Abstract. This article presents the basic philosophical assumptions underlying the evaluation of military action from the perspective of Catholic social teaching. While stressing the continuity of the Church's teaching on the ethical dimension of armed conflicts, as well as its profound embedment in the centuries-long tradition of Christian philosophy, the author acknowledges the shift of emphasis in the Church's contemporary position on war from attributing a specific value to war as such to justifying the defense of peace, which at times inevitably involves the employment of military force.
} 
Keywords: ethics of war, ethically justified war, rights of sovereign states, defensive war, military intervention

Henryk Skorowski

skorowski@uksw.edu.pl

Uniwersytet Kardynała Stefana Wyszyńskiego w Warszawie, Instytut Socjologii

Wóycickiego 1/3, 01-938 Warszawa

DOI: 10.21697/spch.2017.53.3.10 